\title{
Qualitative characteristics of water resulting from the introduction of Eucalyptus silviculture in Pampa biome, RS
}

\section{Características qualitativas da água resultante da introdução da silvicultura de eucalipto no bioma Pampa, RS}

\author{
Jussara Cabral Cruz ${ }^{1}$, Mirian Lago Valente ${ }^{1}$, Carine Baggiotto ${ }^{1}$ and Edner Baumhardt ${ }^{1}$ \\ ${ }^{1}$ Universidade Federal de Santa Maria, Santa Maria, RS, Brazil \\ E-mails: jussaracruz@gmail.com (JCC), mirian_sm@yahoo.com.br (MLV), carine.bg@hotmail.com (CB), ednerb@gmail.com (EB)
}

Received: January 27, 2016 - Revised: April 24, 2016 - Accepted: May 18, 2016

\begin{abstract}
This study aimed to present the effect on surface water quality of the introduction of eucalyptus forestry in areas that were traditionally used for extensive cattle farming in the Pampa biome, by comparing two paired watersheds located in the municipality of Rosário do Sul, one of them used for forestry and the other in an anthropized natural grassland condition in the Pampa biome. For this purpose, every fifteen days the following parameters were collected and analyzed in two watersheds with different land uses (watershed with grassland and extensive livestock farming - GW and watershed with Eucalyptus - EW) between the months of August 2011 and August 2012: $\mathrm{pH}, \mathrm{EC}$, temperature, turbidity and concentrations of $\mathrm{SO}_{4}^{2-}, \mathrm{K}^{+}, \mathrm{Ca}^{2+}, \mathrm{Mg}^{2+}, \mathrm{Cl}^{-}, \mathrm{BOD}_{5,20}, \mathrm{SS}$, DS, alkalinity, total coliforms and Escherichia coli. Water quality and land use parameters averages were compared using the t-Test to account for the land use and seasonality. It was concluded that the introduction of forestry activity together with the areas of environmental protection required by the Brazilian legislation (Permanent Preservation Areas - PPA plus Legal Reserve - LR), contributed to the increased concentrations of conductivity, dissolved solids, alkalinity and calcium, and the decreased concentrations of total coliforms and Escherichia coli.
\end{abstract}

Keywords: Eucalyptus spp.; Land use; Water quality; Small watersheds.

\section{RESUMO}

Este trabalho objetivou apresentar a influência na qualidade da água superficial resultante da introdução da atividade de silvicultura de eucalipto em áreas com uso tradicional (pecuária extensiva) no bioma Pampa, por meio da comparação de duas em bacias hidrográficas pareadas e localizadas no município de Rosário do Sul, RS, uma sob uso da silvicultura e outra em condição de campo natural antropizado no bioma Pampa. Para tanto, quinzenalmente, realizaram-se coletas de água e a análise dos parâmetros pH, CE, temperatura, turbidez e as concentrações de: $\mathrm{SO}_{4}^{-}, \mathrm{K}^{+}, \mathrm{Ca}^{2+}, \mathrm{Mg}^{2+}, \mathrm{Cl}, \mathrm{DBO}_{5,20}, \mathrm{SS}, \mathrm{SD}$, alcalinidade, coliformes totais e Escherichia coli em duas bacias hidrográficas pareadas com diferentes usos do solo (campo com pecuária extensiva e silvicultura de eucalipto) durante os meses de agosto de 2011 a agosto de 2012. Após, avaliou-se a sazonalidade e a influência do uso do solo, por meio de comparação de médias por meio do Teste t entre os parâmetros de qualidade de água e o uso do solo. Por meio dos resultados, conclui-se que a introdução da atividade de silvicultura em conjunto com as áreas de proteção ambiental exigidas pela legislação (APP + RL) contribuiu para a redução das concentrações coliformes totais e Escherichia coli e para o aumento das concentrações de condutividade elétrica, sólidos dissolvidos, alcalinidade e cálcio para o período monitorado.

Palavras-chave: Eucalyptus spp.; Uso do solo; Qualidade da água; Bacia hidrográfica. 


\section{INTRODUCTION}

In Brazil, the Pampa biome only exists in the state of Rio Grande do Sul (RS) covering $2.07 \%$ of the Brazilian territory (IBGE, 2012). The biome comprises large areas of natural grasslands with a floristic matrix composed by forest formations interspersed along the watercourses (BOLDRINI, 2009).

According to the Ministry of the Environment (BRASIL, 2012b), this ecosystem has presented extensive cattle farming as the main economic activity in the region since the time of the Iberian Colonization, with the introduction of livestock by the Jesuits around 1634, which characterizes the formation of the state and its regional identity.

Besides the traditional use of extensive cattle farming and almost one century of agricultural activity, it was only in 2004 that large areas of the Pampa biome were changed to silviculture, although until that time there had been no significant activity involving forestry. During this period also, a few forestry companies were established and contributed to a mean annual increase of $11 \%$ of the area where eucalyptus was planted in the State. In 2011, the planted area in RS, corresponded to $5.7 \%$ (280.198 ha) of the total national area planted to genus Eucalyptus spp., contributing to keep Brazil in the world ranking of forestry production (ABRAF, 2012).

As eucalyptus silviculture spread in the southern half of the state, many questions arose about the possible changes in soil characteristics and their effects on the water resources in these environments. However the activity of silviculture includes protecting the Permanent Preservation Areas (PPAs) and the Legal Reserve (LR) during the planning phase, and also a number of studies regarding the possible environmental impacts, as determined by law.

The use of the watershed as a territorial unit for planning and management purposes was instituted by Federal Law 9,433 of January 8, 1997 (BRASIL, 1997). Thus, the basin can be considered an essential geomorphological unit that comprises the mechanisms triggered in the environment by means of its forms which flow together until a single bed results, called the mouth (CALIJURI; BUBEL, 2006; SILVEIRA, 2001), and water quality is ruled by CONAMA Resolution 357/2005 (BRASIL, 2005).

Brooks, Ffolliott and Magner (1991), Câmara (2004), Gardiman Junior (2012), Likens (1985), Lima and Zakia (2006) and Moster (2007) presented examples of studies that used experimental watersheds as a tool to evaluate the environmental effects of land use. Brown et al. (2005) mention that the "paired basins" method is very effective since it detects the effects of changes in land use, one of the main instruments to support a policy of water resources planning and management being to monitor the water quality parameters (LEMOS; FERREIRA NETO; DIAS, 2010).

Research in the "campanha" region of RS relating eucalyptus silviculture to the characteristics and possible effects on this environment is still very incipient (CALIL, 2008; CORREAA, 2011), and also as regards possible changes of activity in the water course as demonstrated by Baumhardt (2010), Dambrós (2011) and Consensa (2012), Peláez (2014) which implies lack of information about the possible effects of silviculture on the physical, chemical and biological variables of water.
In the light of the questions about the insertion of silviculture into the Pampa biome, the article considers the hypothesis that silviculture, replacing its traditional use, may help improve the qualitative characteristics of water sampled at the mouth of each basin, a site in which the surface water synthetizes all of the effects of the use of the drained area (IRION et al., 2003).

Based on this assumption, the article evaluates the influence of the introduction of eucalyptus silviculture into areas with a traditional use (extensive cattle farming), in the Pampa biome. The evaluation was done by interpreting the physicochemical and biological characteristics of surface water performed in two paired watersheds, located in a Pampa biome region, one used for eucalyptus silviculture and the other an anthropized natural grasslands.

\section{MATERIALS AND METHODS}

\section{Location and characterization of the investigated areas}

The study was developed in two watersheds located in the Santa Maria River Basin, which lies between the Santa Maria and Ibicuí da Armada rivers in the southwest of RS. The watershed with grassland and extensive livestock farming $(\mathrm{GW})$ is a private property and the watershed with Eucalyptus (EW) belongs to the Stora Enso S/A company. The areas were selected based on the principle of the methodology of paired watersheds, as regards the similarity of the soil, relief and rainfall regime characteristics, but with different land uses. The two watershed are independent from each other, and $13 \mathrm{~km}$ apart in a straight North/South line, under the altitudes of 153 and 133 meters for EW and GW, respectively (Figure 1).

The climate of the region, according to the Köppen climate classification, is Cfa, humid subtropical with a hot summer (ALVARES et al., 2013). Soil is classified as Argissolo Bruno Acinzentado Alítico in the Brazilian Soil Classification System (EMBRAPA, 2006), as originated from siltstone and sandstone in transition with Planosols from the Central Depression (STRECK et al., 2008) and Abruptic Alisols (Alumic, Differentic), respectively in World Reference Base for Soil Resources (IUSS, 2014).

EW comprises an area of about $0.95 \mathrm{~km}^{2}$, and consists of $0.49 \mathrm{~km}^{2}$ to be used to plant eucalyptus, with the following species: Eucalyptus urograndis, Eucalyptus grandis and Eucalyptus dunnii, where $91.4 \%$ of the plants cultivated belong to species Eucalyptus urograndis, with wood for cellulose production. The remainder of the area $\left(0.46 \mathrm{~km}^{2}\right)$ corresponds to the environmental protection areas using gallery forest and grasslands without the presence of cattle, which corresponds to $48 \%$ of the basin area, a percentage higher than that recommended by Brazilian legislation (20\%), according to Law $n^{\circ}$ 12.651, of May 25, 2012 (BRASIL, 2012a). The other watershed (GW) covers a catchment area equal to $0.21 \mathrm{~km}^{2}$, with the traditional use of the Pampa biome, extensive livestock in an anthropized natural grassland. The drainage network has less riparian protection compared to EW concentrated in the mouth area where the cattle has access to the drainage system. 


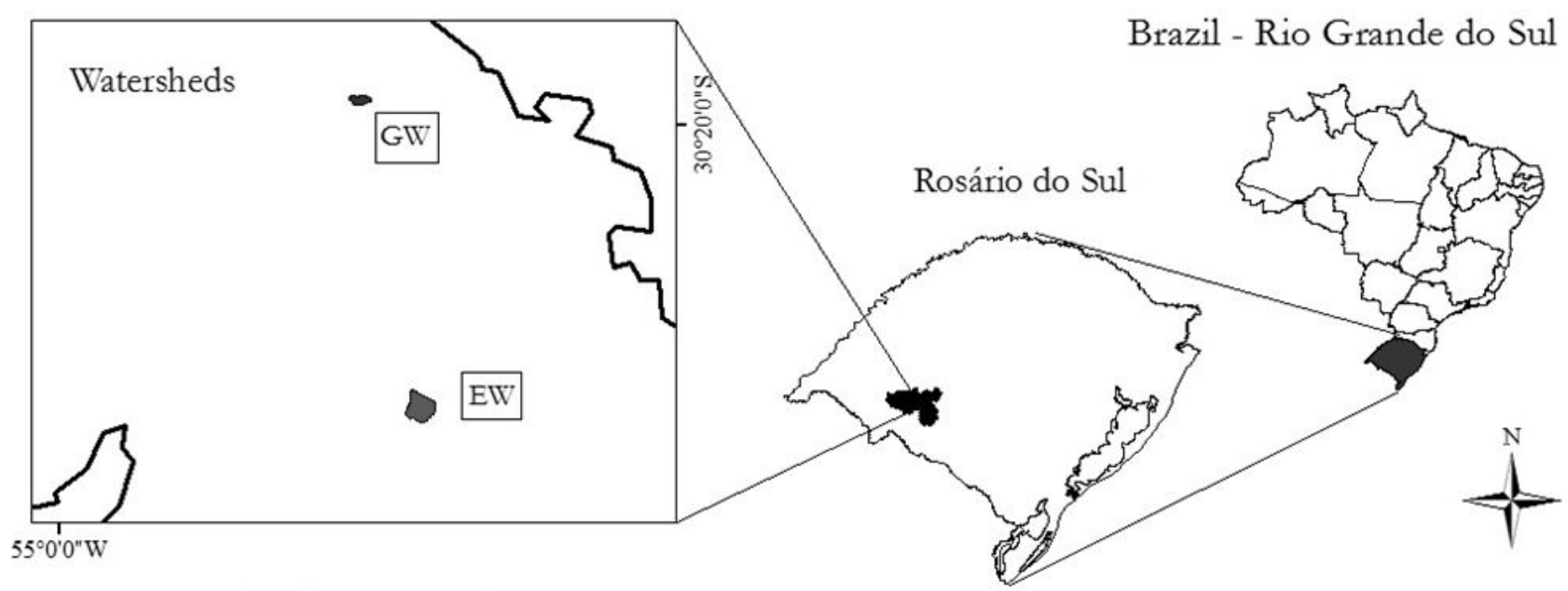

Eucalyptus Watershed $\left(0.95 \mathrm{~km}^{2}\right)$
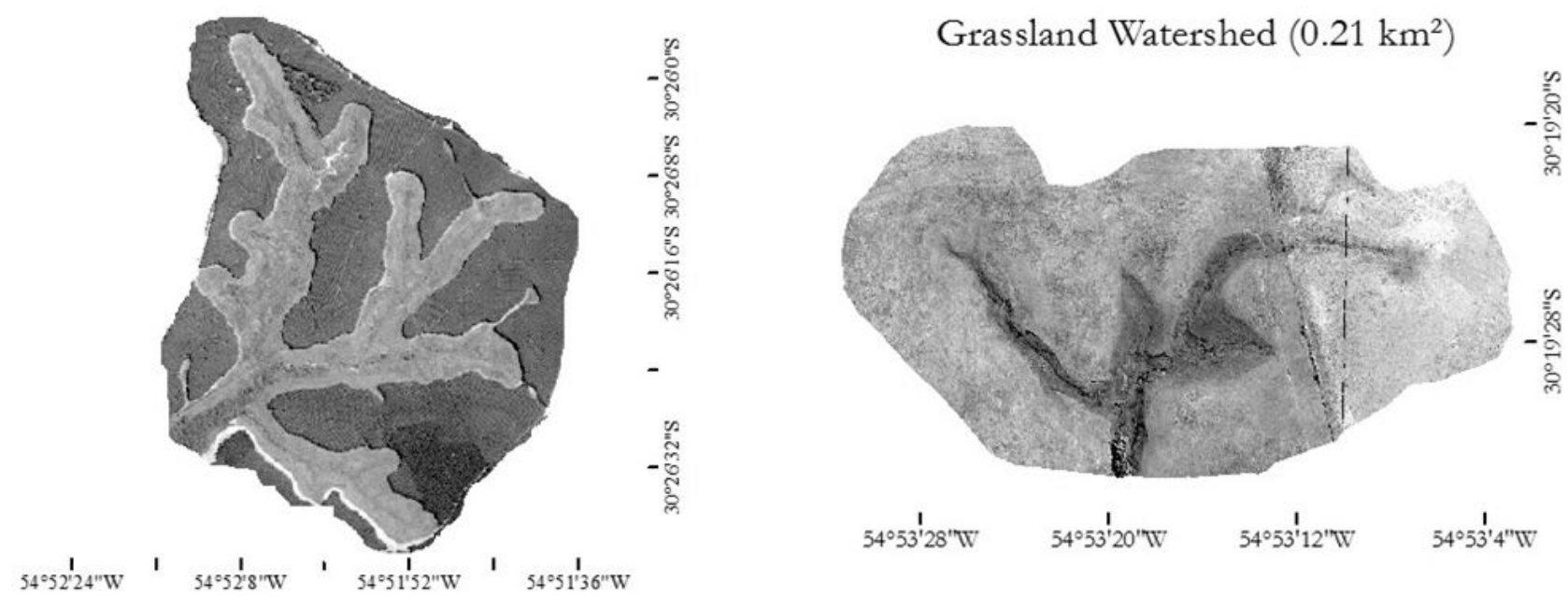

Figure 1. Location of the watersheds investigated, Grassland Watershed (GW) and Eucalyptus Watershed (EW), in the municipality of Rosário do Sul, RS.

\section{Instrumentalization of the areas}

Each watershed was instrumentalized with a $90^{\circ}$ triangular spillway (built at the mouth) with a thin wall made from a $3 \mathrm{~mm}$ galvanized steel sheet, according to the Technical Standard of CPRH N. 2.004; a stilling well $60 \times 60 \times 80 \mathrm{~cm}$ high, where the pressure transducers were installed for the automatic measurement of discharge levels. In an adjacent clearing, 4 rainfall collector funnels were installed. The water quality sampling points in each catchment were located at the respective mouth and upstream from the spillway in order to remain outside the backwater area of influence.

\section{Water collection and physicochemical and biological analyses}

Between the months of August 2011 and August 2012, surface water sampling was performed at the mouth to the basins, approximately every 15 days, making up a total of 30 samples, five of the samples in summer, 6 in autumn, 9 in winter and 10 in spring.
The samples were stored in containers with an 0.5 liter capacity and transported to the Forest Ecology Laboratory (LABEFLO) of the Department of Forestry Sciences at UFSM for later analysis of the cations $\left(\mathrm{Mg}^{2+}, \mathrm{Ca}^{2+}, \mathrm{K}^{+}\right)$and anions $\left(\mathrm{SO}_{4}^{2-}, \mathrm{Cl}\right)$; the samples contained in the 5-liters containers were sent to the Laboratory of Engineering and the Environment (LEMA) of the UFSM Center of Technology for analysis of the parameters: hydrogenionic potential $(\mathrm{pH})$, electric conductivity (EC), turbidity (Turb.), alkalinity (Alk.), suspended solids (SS) and dissolved solids (DS), biochemical oxygen demand $\left(\mathrm{BOD}_{5 ; 20}\right)$, total coliforms (TC) and Escherichia coli. Except for the analysis of water temperature (performed in situ), the others followed the analytic procedures recommended by APHA (1995).

\section{Data processing}

The data were tabulated and statistically analyzed using the ASSISTAT 7.6 beta software (SILVA, 2012) applying the $t$ test and they were compared between the different areas of study and between the seasons of the year. 


\section{RESULTS AND DISCUSSION}

In Table 1, below, the $t$ test is applied to the means of the water quality parameters for the different areas of study based on the seasons of the year and the means of GW and EW followed by the same letter mean that they are not significantly different from each other, applying the t test.

Total precipitation recorded for the months was 583.8 and $721.6 \mathrm{~mm}$, for GW and EW (Figure 2), respectively, while the annual mean of the historical series corresponded to $1444.3 \mathrm{~mm}$. These values corresponded to only $40.42 \%$ (in GW) and $49.96 \%$ (in EW) of the mean annual precipitation observed in the historical series belonging to one of the farms monitored during the period between 1953 and 2010. Therefore it should be underscored that during the monitoring period, from the months of November 2011 to May 2012, the state of Rio Grande do Sul suffered an intense drought, as a consequence of the La Nina phenomenon, in which approximately two hundred days of significantly irregular precipitation caused mean losses of billions in farming and water supply in several communities of the interior,

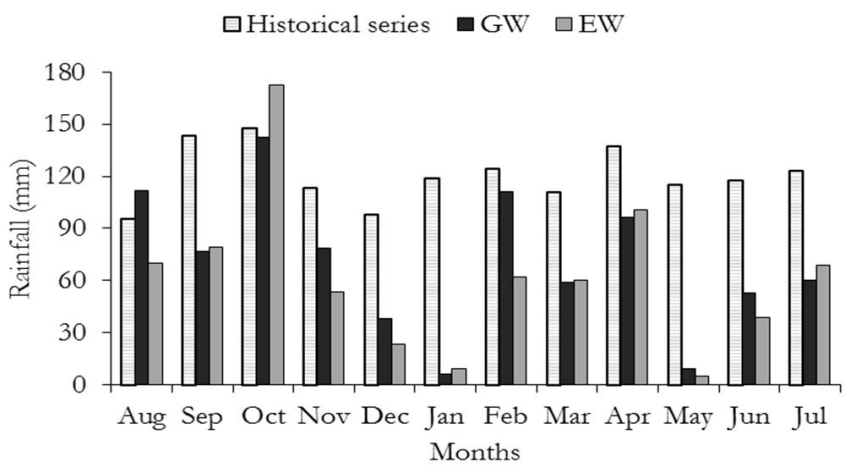

Figure 2. Monthly means of the historical series (1953-2010) and of the period monitored in the watersheds (GW and EW). including the Campanha (CEMETRS, 2012). During this drought, Baumhardt (2014) observed that although evapotranspiration is not higher in the EW compared to GW, and the mean flow is superior in $\mathrm{GW}$, during the period of intense drought $\mathrm{EW}$ was perennial because of the better recharge provided by silvicultural activity.

The Figure 3 shows the comparative distribution of the values of each variable analyzed for the collections without (s) and with (c) precipitation, in the two areas of study. The turbidity means were equal to 12.47 and 12.42 UNT, respectively for GW and EW, which were not significantly differentiated among the areas and seasons, according to the test applied (Table 1). The results were similar to those found by Mosca (2003), Câmara (2004), Ribeiro (2009), Queiroz et al. (2010) and Lubenow et al. (2012) for the different uses. According to Figure 3a, in EW the highest turbidity values were observed for collections with a greater volume of pluviosity. This increase due to rainfall, can be accounted for by the entrainment of organic material (leaves and remnants of decomposing vegetation), and possible soil particles (CETESB, 2009).

The increased turbidity partly justifies the higher values of suspended solids (SS), and especially dissolved solids (DS) in EW, as shown by the ratio curve $1: 1$ (Figure $3 j$ and $3 k$ ) and by the $t$ test analysis (Table 1). However, during the period with the greatest drought, higher values were observed in GW, which are due to the presence of cattle in the area and disturbing the soil, since the water source studied is also a watering hole for the animals. It should be emphasized that the two outstanding points on the graphic (Figure 3a) corresponded to low volumes of precipitation (between 1.1 and $7.4 \mathrm{~mm}$ ), that occurred after a long dry period. In this case, in the forested area, part of this precipitation was lost to interception and evaporation, resulting in less surface runoff and less entrainment of sediment, while in the field the cattle's activity may have influenced the higher turbidity values.

The mean values of $\mathrm{pH}$ were 6.23 (GW) and 7.23 (EW) with significant differences among the areas of study to a $1 \%$

Table 1. Mean values of the physical, chemical and biological attributes of surface water in the watersheds with different land uses (GW and EW) for the monitored seasons of the year.

\begin{tabular}{|c|c|c|c|c|c|c|c|c|}
\hline \multirow{2}{*}{ Parameters } & \multicolumn{2}{|c|}{ Spring } & \multicolumn{2}{|c|}{ Summer } & \multicolumn{2}{|c|}{ Autumn } & \multicolumn{2}{|c|}{ Winter } \\
\hline & GW & EW & GW & EW & GW & EW & GW & EW \\
\hline${ }^{* *} \mathrm{pH}$ & $6.24 \mathrm{c}$ & $7.07 \mathrm{~b}$ & $6.13 c$ & $7.32 \mathrm{ab}$ & $6.06 c$ & $7.40 \mathrm{a}$ & $6.29 \mathrm{c}$ & $7.28 \mathrm{ab}$ \\
\hline n.s. Turb & $11.26 \mathrm{ab}$ & $19.95 \mathrm{a}$ & $18.01 \mathrm{ab}$ & $6.46 \mathrm{~b}$ & $8.05 \mathrm{ab}$ & $7.80 \mathrm{~b}$ & 11.43ab & $10.03 \mathrm{ab}$ \\
\hline${ }^{* *} \mathrm{EC}$ & $33.03 \mathrm{~d}$ & $158.42 \mathrm{bc}$ & $40.83 \mathrm{~d}$ & $335.66 \mathrm{a}$ & $46.40 \mathrm{~cd}$ & $375.38 \mathrm{a}$ & $44.13 \mathrm{~d}$ & 265.69ab \\
\hline *TC & $839.01 \mathrm{c}$ & $540.36 c$ & $5907.51 \mathrm{ab}$ & $3847.85 \mathrm{bc}$ & $10016.89 \mathrm{a}$ & $828.55 c$ & $2822.45 b c$ & $2263.20 b c$ \\
\hline n.s. Escherichia Coli & $229.32 \mathrm{a}$ & $102.30 \mathrm{a}$ & $2314.83 a$ & $1455.83 \mathrm{a}$ & $4319.22 \mathrm{a}$ & $97.39 \mathrm{a}$ & $8644.98 \mathrm{a}$ & $95.96 \mathrm{a}$ \\
\hline n.s.s. $\mathrm{BOD}_{5,20}$ & $1.19 \mathrm{~b}$ & $1.70 \mathrm{ab}$ & $2.04 \mathrm{ab}$ & 2.49ab & $1.47 \mathrm{ab}$ & $1.98 \mathrm{ab}$ & $2.06 \mathrm{ab}$ & $3.31 \mathrm{a}$ \\
\hline n.s.sS & $9.49 \mathrm{ab}$ & $13.9 \mathrm{a}$ & $11.84 \mathrm{ab}$ & $5.19 \mathrm{~b}$ & $11.10 \mathrm{ab}$ & 7.29ab & $5.36 \mathrm{~b}$ & $4.4 \mathrm{~b}$ \\
\hline${ }^{* *} \mathrm{DS}$ & $35.56 \mathrm{~d}$ & $137.75 \mathrm{c}$ & $55.39 \mathrm{~d}$ & $219.72 \mathrm{ab}$ & $71.50 \mathrm{~d}$ & $234.87 \mathrm{a}$ & $48.17 d$ & $182.43 \mathrm{bc}$ \\
\hline **Alc. & $12.46 \mathrm{~d}$ & $77.67 \mathrm{c}$ & $17.74 \mathrm{~d}$ & $170.49 \mathrm{ab}$ & $15.63 \mathrm{~d}$ & $194.21 \mathrm{a}$ & $15.19 \mathrm{~d}$ & $130.86 \mathrm{~b}$ \\
\hline **Temp. & $19.03 \mathrm{~b}$ & $17.39 \mathrm{bc}$ & $22.93 a$ & $23.60 \mathrm{a}$ & $17.39 \mathrm{bc}$ & $14.86 \mathrm{~cd}$ & $13.48 \mathrm{~d}$ & $12.49 \mathrm{~d}$ \\
\hline n.s. $\mathrm{Cl}^{-}$ & $0.94 \mathrm{~b}$ & $1.44 \mathrm{ab}$ & $2.65 \mathrm{ab}$ & $2.24 \mathrm{ab}$ & $3.40 \mathrm{ab}$ & $2.24 \mathrm{ab}$ & $3.796 \mathrm{a}$ & $3.793 \mathrm{a}$ \\
\hline${ }^{* *} \mathrm{SO}_{4}^{2-}$ & $0.17 \mathrm{c}$ & $1.19 \mathrm{~b}$ & $0.45 c$ & $0.47 \mathrm{c}$ & $0.16 \mathrm{c}$ & $0.57 \mathrm{c}$ & $0.22 \mathrm{c}$ & $1.78 \mathrm{a}$ \\
\hline${ }^{* *} \mathrm{~K}^{+}$ & $1.05 \mathrm{c}$ & $1.31 \mathrm{bc}$ & $2.56 \mathrm{ab}$ & $2.01 b c$ & $3.80 \mathrm{a}$ & $1.61 b c$ & $3.73 \mathrm{a}$ & $2.07 \mathrm{bc}$ \\
\hline${ }^{* *} \mathrm{Mg}^{2+}$ & $1.07 \mathrm{c}$ & $2.01 \mathrm{c}$ & $1.13 c$ & $6.50 \mathrm{a}$ & $1.44 \mathrm{c}$ & $6.60 \mathrm{a}$ & $1.57 \mathrm{c}$ & $4.91 \mathrm{~b}$ \\
\hline${ }^{* *} \mathrm{Ca}^{2+}$ & $1.44 \mathrm{c}$ & $12.03 \mathrm{c}$ & $2.28 \mathrm{c}$ & $49.42 \mathrm{a}$ & $2.29 \mathrm{c}$ & $42.08 \mathrm{ab}$ & $2.24 \mathrm{c}$ & $32.22 \mathrm{~b}$ \\
\hline
\end{tabular}

The means followed by the same letter are not statistically different from each other applying the $\mathrm{t}$ test. ${ }^{* *}$ significant to the level of $1 \%$ probability ( $\mathrm{p}<0.01$ ).

* significant to the level of $5 \%$ probability $(0.01 \leq \mathrm{p}<0.05)$. ${ }^{\mathrm{n} . \mathrm{s}}$ non significant $(\mathrm{p} \geq 0.05)$. 

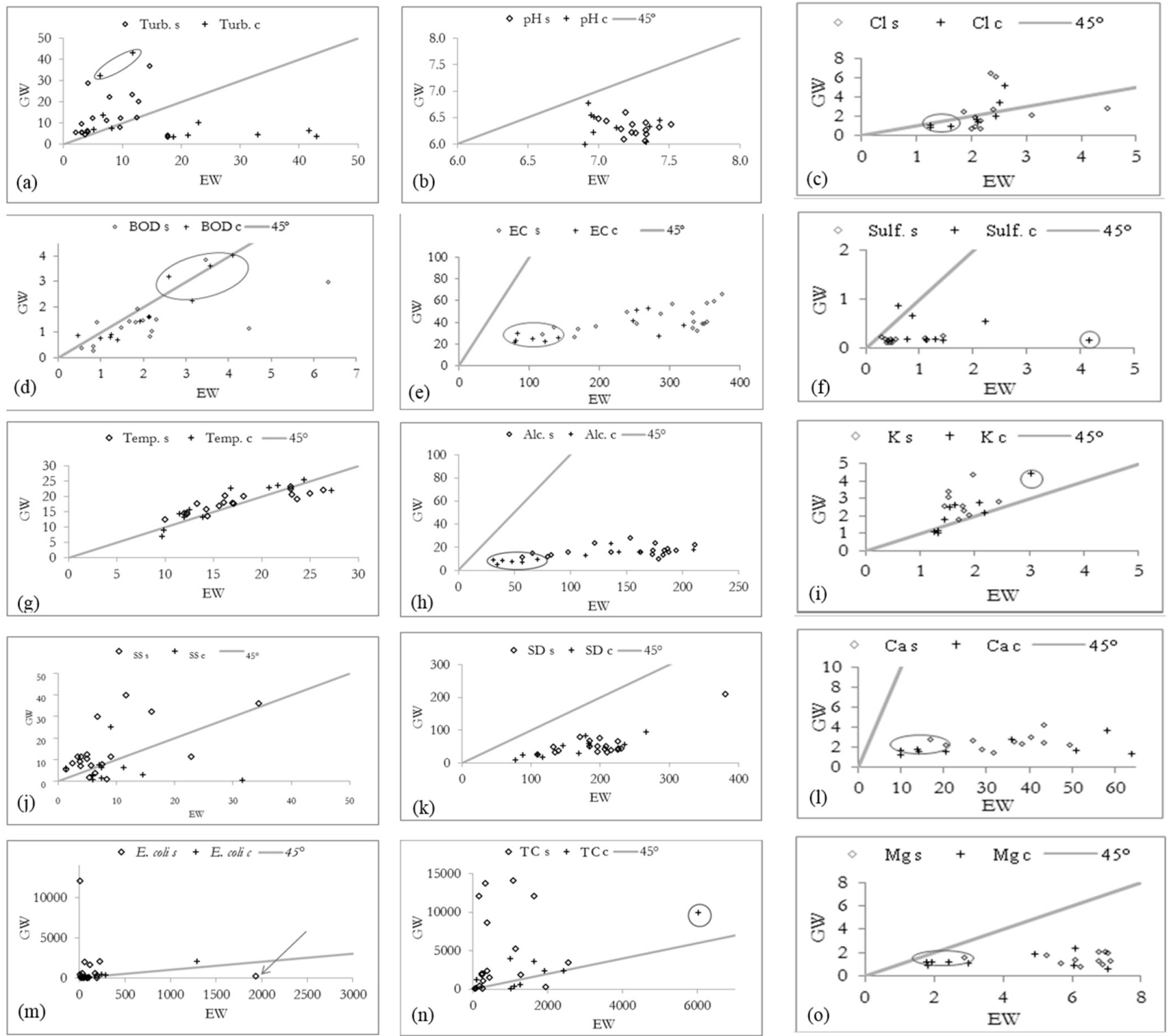

Figure 3. Comparison of the turbidity values (UNT) (a); $\mathrm{pH}(\mathrm{b}) ; \mathrm{Cl}^{-}\left(\mathrm{mg} \mathrm{L}^{-1}\right)(\mathrm{c}) ; \mathrm{BOD}_{5,20}\left(\mathrm{mg} \mathrm{L}^{-1}\right)(\mathrm{d}) ; \mathrm{EC}\left(\mu \mathrm{S} \mathrm{cm}{ }^{-1}\right)(\mathrm{e}) ; \mathrm{SO}_{4}^{2-}\left(\mathrm{mg} \mathrm{L}^{-1}\right)$ (f); temperature $\left({ }^{\circ} \mathrm{C}\right)(\mathrm{g})$; alkalinity $\left(\mathrm{mg} \mathrm{L}^{-1}\right.$ of $\left.\mathrm{CaCO}_{3}\right)(\mathrm{h}) ; \mathrm{K}^{+}\left(\mathrm{mg} \mathrm{L}^{-1}\right)(\mathrm{i}) ; \mathrm{SS}\left(\mathrm{mg} \mathrm{L}^{-1}\right)(\mathrm{j}) ; \mathrm{DS}\left(\mathrm{mg} \mathrm{L}{ }^{-1}\right)(\mathrm{k}) ; \mathrm{Ca}^{2+}\left(\mathrm{mg} \mathrm{L}^{-1}\right)(\mathrm{l})$; Escherichia coli $(\mathrm{NMP} / 100 \mathrm{ml})(\mathrm{m})$; TC $(\mathrm{NMP} / 100 \mathrm{ml})(\mathrm{n})$; and $\mathrm{Mg}^{2+}\left(\mathrm{mg} \mathrm{L}^{-1}\right)(\mathrm{o})$ of water in the different watersheds with eucalyptus and grasslands in collections without (s) and with precipitation (c).

level of probability (Table1) and among the seasons in EW, evidenced by the ratio curve 1:1 (Figure $3 \mathrm{~b}$ ). The values belong to the aquatic life protection intervals in surface waters (6 and9), according to CETESB (2009), 6.0 to 8.5 (LIBÂNIO, 2008) and 4.0 and 9.0 (MOSCA, 2008). The highest values found in EW may be related to the higher concentrations of bicarbonates, especially calcium and magnesium (LIBÂNIO, 2008), which agrees with what was observed in $\mathrm{EW}$ for cations $\mathrm{Ca}^{2+}$ and $\mathrm{Mg}^{2+}$, as will be better described below, and also the relationship with the geochemical characteristics at the site. These values may also be related to the processes of leaching or release of total bases from the accumulation of leaf litter present in the creek protection area (PPA + LR) because of the low flows that occurred in the watercourse during the monitored period.

Farley et al. (2008) observed, in paired water sources in the Pampa biome in Argentina and Uruguay, mean values of 7.2 and 6.5, respectively, for grassland uses and planting eucalyptus. Mosca (2008) observed pH values between 6 and 7 in a watershed where eucalyptus had been planted in the Cerrado, without much variation during the dry and rainy periods, according to what has been observed in the present study.

The EC means corresponded to 39.08 and $253.49 \mu \mathrm{S} \mathrm{cm}^{-1}$ for GW and EW, respectively. In general, the higher values of EC were observed in EW, as highlighted in the graphic (Figure 3e). Collections in rainy periods with higher $\mathrm{EC}$ values corresponded to events with low volumes of precipitation that occurred after a long dry period, and therefore are more closely related to the high concentration of solutes in water in the EW. Esteves (1998) found in tropical regions that the EC of water is more closely related to the geochemical composition and to dry and rainy conditions than to the trophic state of a watercourse. The values are differentiated, statistically, among the investigated areas and were similar between the seasons for the area of study (Table 1).

In $\mathrm{EW}$, a difference is observed among the means for summer and autumn, which corresponds to the dryer period (Figure 3e). It is considered that in continental waters the main ions that contribute 
to increasing EC are: calcium, magnesium, potassium, sodium, carbonates, sulfates and chlorides (LAUERMANN, 2007), the main sources of these ions being related to the dissolution of rocks and soils (CETESB, 2009; LIMA; ZAKIA, 2006); RIBEIRO, 2009). It can thus be inferred that the significant presence of cations $\mathrm{Mg}^{2+}$ and $\mathrm{Ca}^{2+}$ (Figure 31-3o) accounts for part of the EC values found in EW. It is possible that a contribution of these ions is due to the base runoff as regards the high EC values, and not only under the influence of land use, however, this hypothesis requires further evidence. The means of $\mathrm{Ca}^{2+}$ were 2.07 and $33.94 \mathrm{mg} \mathrm{L}^{-1}$, for GW and EW, respectively. The values were similar among land uses during the spring (greater pluviosity), however for the other seasons of the year (dry) higher $\mathrm{Ca}^{2+}$ contents were observed in EW. The values observed for $\mathrm{Mg}^{2+}$, in EW, are similar to those found by Gardiman Junior (2012). The means of $\mathrm{Mg}^{2+}$ were 2.70 and $2.46 \mathrm{mg} \mathrm{L}^{-1}$, for GW and EW. The values can be explained by the accumulation of organic material, but also by their underground origin. According to Câmara, Lima and Zákia (2006), magnesium reaches the outflow mainly via base runoff, which corresponds to the discharge maintained by the groundwater that exists in the aquifers, whose main source is rainwater that infiltrates into the soil and percolates to the deeper strata, and is thus a good indicator of water infiltration into the soil.

The mean contents of $\mathrm{K}^{+}$were 2.79 and $1.75 \mathrm{mg} \mathrm{L}^{-1}$ in GW and EW, respectively. The highest potassium values were observed in GW, with higher concentrations of the element in the dryer period (Table 1), and the value observed for collection with rainfall (highlighted in Figure 3i) corresponded to an event with low precipitated volumes. The potassium concentrations are within the interval normally observed in natural waters $\left(<10 \mathrm{mg} \mathrm{L}^{-1}\right)$. These low values may be related to the high solubility of the element in these environments, and it is rapidly incorporated into the mineral structures and accumulated in the aquatic biota, since it is an essential element for their nutrition (CÂMARA; LIMA; ZÁKIA, 2006). Ranzini and Lima (2002) looked at potassium values in water between 1.35 and $1.80 \mathrm{mg} \mathrm{L}^{-1}$ in watershed reforested with eucalyptus (LUCAS; FOLEGATTI; DUARTE, 2010). The same authors mention that during dry periods, there is a higher concentration of solutes and mineral elements such as potassium because of the lower discharge. This finding is consistent with what was found in the grasslands that presented higher potassium values for collections without precipitation.

Câmara (2004) also found higher concentrations of magnesium, calcium and conductivity related to the reduction of the creek discharge in water sources where there was eucalyptus. Considering that, according to Likens et al. (1967), the loss of cations $\mathrm{Ca}^{+2}, \mathrm{Mg}^{+2}$ and $\mathrm{K}^{+}$in the surface waters of watercourses is due mainly to the geological weathering process, it can be inferred that the hydrologic regime of the watershed may be influencing the exit of ions $\mathrm{Ca}^{+2}, \mathrm{Mg}^{+2}$ e $\mathrm{K}^{+}$in the outflow, since the time of permanence of groundwater, together with the low pluviometric indices, promotes interaction between this and the deeper strata of the soil, and especially with the rock alteration zones, consequently releasing a larger amount of solutes into the watercourse (ARCOVA; CICCO; LIMA, 1985). The means of these cations were the contrary of those observed by Farley et al. (2008) in areas used for grasslands and eucalyptus. The concentrations observed in EW were higher than the confidence interval estimated by Câmara, Lima and Zákia (2006) for $\mathrm{Ca}^{2+}, \mathrm{Mg}^{2+}$ and below for $\mathrm{K}^{+}$. However, the same authors mention that $\mathrm{Ca}^{2+}$ is rapidly dissolved from rocks rich in calcium minerals, such as carbonates and sulfates, and usually presents concentrations below $15 \mathrm{mg} \mathrm{L}^{-1}$, in natural waters. In general, lower values were observed during the periods with greater pluviosity (highlighted in the graphic of Figure 31), except for the four collections with rainfall, that occurred during the dry period (low precipitated volume and less runoff formation) in which higher values were observed, as previously discussed.

The means for $\mathrm{Cl}^{-}$were 2.70 and $2.46 \mathrm{mg} \mathrm{L}^{-1}$ for $\mathrm{GW}$ and EW, respectively, and higher chloride values were observed during the collections without pluviosity in both areas of study (Figure 3c). According to CETESB (2009), this anion is found in the groundwaters, from the percolation of water through soils and rocks, emphasizing as a possible source of contribution the base runoff in EW, as previously mentioned.. On the other hand, in surface waters, major sources of chloride are cattle farming wastes, partially explaining the values observed in GW. For the sulfate anion, the means were $1.10(\mathrm{EW})$ and $0.25 \mathrm{mg} \mathrm{L}^{-1}(\mathrm{GW})$, evidenced in the comparative graphic (Figure $3 \mathrm{f}$ ). These concentrations were lower than those observed in a study that covered various watersheds with forests and agriculture in Slovakia (PEKÁROVÁ; PEKÁR, 1996). The same authors correlated the high concentrations with the substrate of the areas of study, in agreement with what was found by Fernandes et al. (2012), who mention the dissolution of soils and rocks as a source of sulfate in natural waters. According to CETESB (2009), sulfate $\left(\mathrm{SO}_{4}^{2-}\right)$ is one of the most abundant ions in nature, and in natural waters the main source of sulfate occurs due to the dissolution of soils and rocks, and by sulfide oxidation. The means were the same, significantly, for summer and autumn (dry periods), according to Table 1.

The means of TC were $3616.83(\mathrm{GW})$ and $987.25 \mathrm{NMP} / 100 \mathrm{ml}$ $(\mathrm{EW})$, with significant differences between the areas during autumn (Table 1), at a 1\% level of probability. The highest values observed in GW occurred for the period with the greatest drought, except for a collection that took place after the rainfall event (low volume precipitated after a long dry period, probably with low surface runoff and consequently, with a small capacity for dilution, highlighted (Figure 3n). In general, eucalyptus silviculture, as this activity was implemented, with $48 \%$ of the area for PPA and a legal reserve, without the presence of cattle, helps lower the values of this variable at the monitored site (EW), compared to those of the GW watershed, whose traditional activity is cattle farming. This result was expected, and confirmed by the tests. It should also be observed that these bacteria are not exclusively of fecal origin, according to the considerations of OMS (1995) and Von Sperling (2005).

As to Escherichia coli, the means corresponded to 366.0 (ranging from 5.0 to 5231.0) and 2656.98 (14.35 and 48392.0) $\mathrm{NMP} / 100 \mathrm{ml}$ for GW and EW, respectively. The relationship beween cattle farming and high values observed is seen in GW, since part of the animal waste tends to run off towards the creek when flash floods occur, raising the number of bacteria. The graphic (Figure $3 \mathrm{~m}$ ) shows that the highest concentrations of Escherichia coli occurred during the dryest periods, wich can be explained by the 
cattle farming at GW, and also by the accumulation of these wastes because of the low level of water in the creek. Contamination by the Escherichia coli bacteria in EW is explained by the presence of wastes of wild animals, such as hares, deer and pampas foxes that are sometimes seen in the area of study. However, the high amount of Escherichia coli (highlighted in Figure $3 \mathrm{~m}$ ) in EW, an exceptional value, is believed to have been due to the occasional invasion of cattle in the area of study, because during one of the field trips, a few heads of cattle were observed close to the watershed that was being studied. Since the planted areas planted are extense (5,600 ha) with fragile fences, the cattle from neighboring areas may get in, and it takes up to two months to find livestock that strays into the forest.

The mean values of $\mathrm{BOD}_{5,20}$ corresponded to 1.59 and $2.14 \mathrm{mg} \mathrm{L}^{-1}$ for GW and EW, respectively, and there are no differences between the areas and the seasons (Table 1). These values are lower than those observed by Campello et al. (2005) in the National Forest of São Francisco de Paula in RS, which showed values between 2.83 and $3.34 \mathrm{mg} \mathrm{L}^{-1}$, superior to those observed by Ribeiro (2009) in rural watersheds used for native forest, reforestation and agriculture, whose values ranged from 0.65 to $1.31 \mathrm{mg} \mathrm{L}^{-1}$ and similar to those of Lubenow et al. (2012) where a value of $1.52 \mathrm{mg} \mathrm{L}^{-1}$ was found in an area preserved around the source, in the municipality of Irati (PR). The highest values of $\mathrm{BOD}_{5,20}$, in $\mathrm{EW}$, during the dry period (winter), are supposedly related to the greater presence of organic matter accumulated in the watercouse because of the long dry period that occurred during the study. Lower values were found during the collections with greater pluviosity (Figure 3d), which may be due to the dilution factor of the $\mathrm{BOD}_{5,20}$. concentration. However, events were observed with high values (points highlighted on the graphic), which occur for periods with less precipitation, and these are found after a dry period of 2 and even 3 months, which is related to the greater accumulation of organic matter in the watercourses.

The SS means were 11.42 and $9.03 \mathrm{mg} \mathrm{L}^{-1}$, for GW and EW, respectively, which did not present significant differences between the areas. These values are below the confidence interval (CI) estimated by Câmara, Lima and Zákia (2006), in an area with eucalyptus and within the the CI for what was observed in a secondary forest. The highest values found in GW occurred during the period with the most severe drought (Figure 3j). Moreover, the increase may be due to the soil that was disturbed by cattle.

The DS means were 50.97 and $184.32 \mathrm{mg} \mathrm{L}^{-1}$ for GW and EW, respectively. The values observed in EW are different from those found in GW, and are also superior to the DS concentrations observed by Lubenow et al. (2012), who found 15.5 (SS) and $20 \mathrm{mg} \mathrm{L}^{-1}$ (DS) in a water source area protected by gallery forest, 16.5 (SS) and 60.5 (DS) in areas with access to animals and without the protection of vegetation, and in an area under crops they found 13.5 (SS) and $70 \mathrm{mg} \mathrm{L}^{-1}$ (DS). The lowest values of DS in both areas were recorded during the period with the greatest pluviosity (spring). As to DS, in EW higher concentrations are found during the dryest period (Figure 3k), again emphasizing the possibility of a greater accumulation of organic matter (decomposition, leaching and ion dissolution), or as a result of very biogeochemical characteristics in the area of study, as mentioned previously.
As to alkalinity, the mean concentrations were 15.15 and $128.30 \mathrm{mg} \mathrm{L}^{-1}$ of $\mathrm{CaCO}_{3}$, respectively, for GW and EW, which are statististically differentiated (Table 1), as evidenced in the graphic (Figure 3h). Outstanding are the collections with greater precipitated volumes in which there are the lowest concentrations of alkalinity. On the other hand, the highest values observed during the other collections with rainfall (low volumes of incident precipitation) were preceded by long dry periods. The elevated mean found in EW explains the increased $\mathrm{pH}$ found in the area of study. According to Mosca (2008) the capacity to neutralize acids in an aqueous system depends on some compounds such as bicarbonates, carbonates and hydroxides.

The mean values for temperature were $17^{\circ} \mathrm{C}$ (ranging from 9.7 to $\left.27.2^{\circ} \mathrm{C}\right)$ for $\mathrm{EW}$, and $18^{\circ} \mathrm{C}\left(7.0\right.$ to $\left.25.5^{\circ} \mathrm{C}\right)$ for $\mathrm{GW}$. The means were similar to those observed by Arcova and Cicco (1999), Sabara (1999) and Bueno et al. (2005), in areas where eucalyptus is planted. Câmara (2004) observed higher temperatures in microbasins with grasslands than in afforested areas. According to the $\mathrm{t}$ test, both areas presented similar means at each season of the year (Table 1), as evidenced by the comparative curve of $45^{\circ}$ (Figure 3g).

According to Lima (1996), the characteristics that consider the outflow water quality parameters in areas with forest species show that the final quality of water, under natural conditions, depends more on the geology, watershed soil and rainfall regime in the region, through the interaction of hydrological processes involved in outflow generation by the body of water.

The results show that for this case study, the considerations of Gardiman Junior (2012) were valid, for whom the highest averages of water quality variables observed in the forested basin may be associated: with the characteristics of the physical environment of the watershed investigated itself; the reduction of water velocity found in the water body and, consequently the low flow that contributed to increasing the concentration of some variables; the greater input of organic matter from the riparian vegetation that exists there and the chemical characteristics of the soil.

\section{CONCLUSIONS}

The results of the analyses of the following variables: total solids, dissolved solids, turbidity, $\mathrm{pH}, \mathrm{Ca}^{2+}, \mathrm{Mg}^{2+}$ and $\mathrm{EC}$, indicate a significant influence of the activity on the Pampa biome, and the highest values in the watershed are from eucalyptus silviculture (EW) compared to the watershed with extensive livestock in an anthropized natural grassland (GW) and these results can be ascribed to the leaching of leaf litter. On the other hand, the great influence of cattle farming is observed in GW, when the total coliform and Escherichia coli parameters are analyzed, with significantly higher values than those observed in EW. It also became evident that the influence of the variation of concentrations was a result of drought or of the presence of antecedent rainfall. In periods of rainfall there are signs of the influence of entrainment on the values of the quality variables, such as suspended and dissolved solids, and turbidity which in EW are greater in the presence of rain, probably due to the entrainment of organic matter present in the litter. On the other hand, during dry periods the highest 
values occur in GW, showing the influence of the presence of cattle near the water body.

It is thus concluded that the silviculture monitored in this study reduced the concentrations of total coliforms and Escherichia coli and increased the concentrations of electric conductivity, dissolved solids, alkalinity and acid.

\section{ACKNOWLEDGEMENTS}

We thank all those who collaborated to peform this study: CAPES, CNPQ, FINEP, FAPERGS, CT-HIDRO, LABEFLO, UFSM, Group GERHI, STORA ENSO and Mr. Ildo José Spanevello, owner of Fazenda São Carlos, the farm where part of this research was performed.

\section{REFERENCES}

ABRAF - ASSOCIAÇÃO BRASILEIRA DE PRODUTORES DE FLORESTAS PLANTADAS. Anuário estatístico da ABRAF 2012 ano base 2011. Brasília, 2012. 145 p.

ALVARES, C. A.; STAPE, J. L.; SENTELHAS, P. C.; GONÇALVES, J. L. M.; SPAROVEK, G. Köppen's climate classification map for Brazil. Meteorologische Zeitschrift, v. 22, n. 6, p. 711-728, 2013. http:// dx.doi.org/10.1127/0941-2948/2013/0507.

APHA - AMERICAN PUBLIC HEALTH ASSOCIATION. Standard methods for the examination of water and wastewater. 19th ed. Washington, 1995.

ARCOVA, F. C. S.; CICCO, V. Qualidade da água de microbacias com diferentes usos do solo na região de Cunha, Estado de São Paulo. Scientia Florestalis, v. 56, p. 125-134, 1999.

ARCOVA, F. C. S.; CICCO, V.; LIMA, W. P. Balanço dos nutrientes $\mathrm{Ca}+2, \mathrm{Mg}+2, \mathrm{Na}+1, \mathrm{~K}+1$ e NO3-1 em bacia hidrográfica experimental com vegetação natural do Parque Estadual da Serra do Mar - Núcleo Cunha - SP. Piracicaba: IPEF, 1985. v. 31, p. 61-67.

BAUMHARDT, E. Balanço hidrico de microbacia com eucalipto e pastagem nativa na região da campan ha do RS. 2010.139 f. Dissertação (Mestrado em Engenharia Civil) - Universidade Federal de Santa Maria, Santa Maria, 2010.

BAUMHARDT, E. Hidrologia de bacia de cabeceira com encaliptocultura e campo nativo na região da campanha gaúcha. 2014. 166 f. Tese (Doutorado em Engenharia Florestal) - Universidade Federal de Santa Maria, Santa Maria, 2014.

BOLDRINI, I. I. A flora dos campos do Rio Grande do Sul. In: PILLAR, V. P.; MÜLLER, S. C.; CASTILHOS, Z. M. S.; JACQUES, A. V. A. Campos Sulinos: conservação e uso sustentável da biodiversidade. Brasília: MMA, 2009. p. 63-77.

BRASIL. Lei no 9.433 de 08 de Janeiro de 1997. Institui a Política Nacional dos Recursos Hídricos. Diário Oficial [da] República Federativa do Brasil, Brasília, DF, 8 jan. 1997. Available from: <http://www. planalto.gov.br/ccivil_03/leis/L9433.htm>. Access on: 2 mar. 2015.

BRASIL. Resolução CONAMA n 357, de 03 de abril de 2005, dispõe sobre a classificação dos corpos de água e diretrizes ambientais para o seu enquadramento, bem como estabelece as condições e padrões de lançamento de efluentes, e dá outras providências. Diário Oficial [da] República Federativa do Brasil, Brasília, DF, 18 mar. 2005. Available from: <http://www.mma.gov.br/port/conama/ res/res05/res35705.pdf>. Access on: 11 mar. 2012.

BRASIL. Lei no 12.651 de 25 de maio de 2012. Institui o Código Florestal Brasileiro. Diário Oficial [da] República Federativa do Brasil, Brasília, DF, 25 maio 2012a. Available from: <http://www. planalto.gov.br/ccivil_03/_Ato2011-2014/2012/Lei/L12651. htm>. Access on: 2 may 2013.

BRASIL. Ministério do Meio Ambiente - MMA. Pampa. Brasília, 2012b. Available from: <http://www.mma.gov.br/biomas/pampa>. Access on: 22 sept. 2012.

BROOKS, K. N., FFOLLIOTT, P. F.; MAGNER, J. A. Hydrology and the management of watersheds. Iowa: Iowa State University Press, $1991.391 \mathrm{p}$.

BROWN, A. E.; ZHANG, L.; MCMAHON, T. A.; WESTERN, A. W.; VERTESSY, R. A. A review of paired catchment studies for determining changes in water yield resulting from alterations in vegetation. Journal of Hydrology, v. 310, n. 1-4, p. 28-61, 2005. http://dx.doi.org/10.1016/j.jhydrol.2004.12.010.

BUENO, L. F.; GALBIATTI, J. A.; BORGES, M. J. Monitoramento de variáveis da qualidade da água do Horto Ouro Verde - Conchal - SP. Engenharia Agricola, v. 25, n. 3, p. 742-748, 2005. http:// dx.doi.org/10.1590/S0100-69162005000300020.

CALIJURI, M. C.; BUBEL, A. P. M. Conceituação de microbacias. In: LIMA, W. P.; ZAKIA, M. J. B. As florestas plantadas e a água: implementando o conceito da microbacia hidrográfica como unidade de planejamento. São Carlos: RiMa, 2006. cap. 4, p. 45-60.

CALIL, F. N. Aspectos nutricionais de um sistema agroflorestal com eucalipto no sul do Rio Grande do Sul, Brasil. 2008. 144 f. Tese (Doutorado em Engenharia Florestal) - Universidade Federal de Santa Maria, Santa Maria, 2008.

CÂMARA, C. D. Critérios e indicadores para o monitoramento bidrológico de florestas plantadas. 2004. 191 f. Tese (Doutorado em Hidráulica e Saneamento) - Escola de Engenharia de São Carlos, Universidade de São Paulo, São Carlos, 2004.

CÂMARA, C. D.; LIMA, W. P.; ZÁKIA, M. J. B. Critérios e indicadores hidrológicos de monitoramento em microbacias. In: LIMA, W. P.; ZAKIA, M. J. B. As florestas plantadas e a água: implementando o conceito da microbacia hidrográfica como unidade de planejamento. São Carlos: RiMa, 2006. cap. 8, p. 107-140. 
CAMPELLO, F. D.; BRAGA, C. F.; GONÇALVES, C. V.; GONÇALVES, C. S.; FUBRO, D.; SANTOS JÚNIOR, J. E.; RODRIGUES, G. G.; HARTZ, S. M. Avaliação preliminar da qualidade das águas da Floresta Nacional de São Francisco de Paula, RS, Brasil. Revista Brasileira de Biociências, v. 3, n. 1, p. 47-64, 2005.

CEMETRS - CENTRO ESTADUAL DE METEOROLOGIA. A estiagem de 2011 / 2012 e sua influência na produção agropecuária do Rio Grande do Sul. Porto Alegre, 2012. Nota Técnica. Available from: <http://www.cemet.rs.gov.br/upload/20120606155033nota_ tecnica_10_06_06_2012_final.pdf>. Access on: 25 nov. 2015.

CETESB - COMPANHIA AMBIENTAL DO ESTADO DE SÃO PAULO. Relatório de qualidade das águas superficiais do Estado de São Paulo. São Paulo, 2009. Available from: <http://www.cetesb. sp.gov.br/userfiles/file/agua/aguas-superficiais/variaveis.pdf $>$. Access on: 23 july 2012.

CONSENSA, C. B. Precipitação pluviométrica e interna em povoamentos de Eucalyptus spp. em Rosário do Sul, RS. 2012. 95 f. Dissertação (Mestrado em Engenharia Florestal) - Universidade Federal de Santa Maria, Santa Maria, 2012.

CORRÊA, R. S. Ciclagem de nutrientes em Eucalyptus dunni estabelecido no bioma pampa. 2011. 99 f. Tese (Doutorado em Engenharia Florestal) - Universidade Federal de Santa Maria, Santa Maria, 2011.

DAMBRÓS, C. Recarga e flutuação do nivel da água subterrânea em subbacias com floresta e campo nativo. 2011. 120 f. Dissertação (Mestrado em Engenharia Civil e Ambiental) - Universidade Federal de Santa Maria, Santa Maria, 2011.

EMBRAPA - EMPRESA BRASILEIRA DE PESQUISA AGROPECUÁRIA. Sistema Brasileiro de Classificação de Solos. 2nd ed. Rio de Janeiro: Embrapa Solos, 2006.

ESTEVES, F. A. Fundamentos de Limnologia. 2nd ed. Rio de Janeiro: Interciência, 1998. 602 p.

FARLEY, K. A.; PIÑEIRO, G.; PALMER, S. M.; JOBBÁGY, E. G.; JACKSON, R. B. Stream acidification and base cation losses with grassland afforestation. Water Resources Research, v. 44, n. 7, p. W00A03, 2008. http://dx.doi.org/10.1029/2007WR006659.

FERNANDES, M. M.; CEDDIA, M. B.; FERNANDES, M. R. M.; GUIMARÃES, G. S. C. Influência do uso do solo na qualidade de água da microbacia Glória, Macaé - RJ. Engenharia Ambiental, v. 7, n. 3, p. 137-142, 2012.

GARDIMAN JUNIOR, G. Qualidade da água de microbacias hidrográficas sob atividades silviculturais em Aracruz, ES. 2012. 123 f. Dissertação (Mestrado em Ciências Florestais) - Universidade Federal do Espírito Santo, Jerônimo Monteiro, 2012.

IBGE - INSTITUTO BRASILEIRO DE GEOGRAFIA E ESTATÍSTICA. Rio de Janeiro, 2012. Available from: < http:// www.ibge.gov.br/home/presidencia/noticias/noticia_visualiza. php?id_noticia=169>. Access on: 30 sept. 2012.
IRION, C.; SILVA, C.; RETZ, E.; SILVEIRA, G.; CRUZ, J. Balanço de cargas poluidoras pelo monitoramento quali-quantitativo dos recursos hídricos em pequena bacia hidrográfica. Revista Brasileira de Recursos Hidricos, v. 8, n. 1, p. 5-11, 2003. http://dx.doi. org/10.21168/rbrh.v8n1.p5-11.

IUSS - IUSS WORKING GROUP WRB. World Reference Base for Soil Resources 2014: International soil classification system for naming soils and creating legends for soil maps. Rome: FAO, 2014. (World Soil Resources Reports, 106).

LAUERMANN, A. Caracterização química dos efluentes gerados pelo aterro controlado de Santa Maria e retenção de chumbo e zinco por um argissolo da depressão central do Rio Grande do Sul. 2007. 72 f. Dissertação (Mestrado em Ciência do Solo) - Universidade Federal de Santa Maria, Santa Maria, 2007.

LEMOS, M.; FERREIRA NETO, M. F.; DIAS, N. Sazonalidade e variabilidade espacial da qualidade da água na Lagoa do Apodi, RN. Revista Brasileira de Engenharia Agricola e Ambiental, v. 14, n. 2, p. 155164, 2010. http://dx.doi.org/10.1590/S1415-43662010000200006.

LIBÂNIO, M. Fundamentos de qualidade e tratamento de água. 2nd ed. Campinas: Átomo, 2008. 443 p.

LIKENS, G. E. An experimental approach for the study of ecosystems. Journal of Biology, v. 73, p. 381-396, 1985.

LIKENS, G. E.; BORMANN, F. H.; JOHNSON, N. M.; PIERCE, R. S. The calcium, magnesium, potassium, and sodium budgets for a small forested ecosystem. Ecology, v. 48, n. 5, p. 772-785, 1967. http://dx.doi.org/10.2307/1933735.

LIMA, W. P. Impacto ambiental do eucalipto. 2. ed. São Paulo: EDUSP, 1996. $301 \mathrm{p}$.

LIMA, W. P.; ZAKIA, M. J. B. As florestas plantadas e a água: implementando o conceito da microbacia hidrográfica como unidade de planejamento. São Paulo: Rima, 2006. 226 p.

LUBENOW, A. T., et al. Impacto do uso e ocupação da terra na qualidade da água da bacia hidrográfca do rio Nhapindazal, Irati (PR). Ambiência Guarapuava., v. 8, n. 3, p. 845-858, 2012.

LUCAS, A. A. T.; FOLEGATTI, M. V.; DUARTE, S. N. Qualidade da água em uma microbacia hidrográfica do Rio Piracicaba. Revista Brasileira de Engenharia Agricola e Ambiental, v. 14, n. 9, p. 937-943, 2010. http://dx.doi.org/10.1590/S1415-43662010000900005.

MOSCA, A. A. O. Avaliação dos impactos ambientais de plantações de eucalipto no Cerrado com base na análise comparativa do ciclo bidrológico e da sustentabilidade da paisagem em duas bacias de segunda ordem. 2008. 256 f. Tese (Doutorado em Ciências) - Universidade de São Paulo, São Paulo. 2008.

MOSCA, A. R. O. Caracterização hidrológica de duas microbacias visando a identificação de indicadores hidrológicos para o monitoramento ambiental do manejo de florestas plantadas. 2003. 123 f. Dissertação (Mestrado 
em Engenharia Florestal) - Escola Superior de Agricultura Luiz de Queiroz, Universidade de São Paulo, Piracicaba, 2003.

MOSTER, C. Avaliação hidrológica da zona ripária através da análise da água subterrânea ao longo das vertentes de uma microbacia experimental. 2007. 83 f. Dissertação (Mestrado em Recursos Florestais) - Escola Superior de Agricultura “Luiz de Queiroz", Universidade de São Paulo, Piracicaba, 2007.

OMS - ORGANIZAÇÃO MUNDIAL DA SAÚDE. Guias para la calidad del agua potable. Ginebra, 1995. 195 p.

PEKÁROVÁ, P.; PEKÁR, J. The impact of land use on stream water quality in Slovakia. Journal of Hydrology, v. 180, n. 1-4, p. 333350, 1996. http://dx.doi.org/10.1016/0022-1694(95)02882-X.

PELÁEZ, J. J. Z. Hidrologia comparativa em bacias hidrográficas com eucalipto e campo. 2014. 156 f. Tese (Doutorado em Engenharia Florestal) - Universidade Federal de Santa Maria, Santa Maria, 2014.

QUEIROZ, M. M. F.; IOST, C.; GOMES, S. D.; VILAS BOAS, M. A. Influência do uso do solo na qualidade da água de uma microbacia hidrográfica rural. Revista Verde, v. 5, n. 4, p. 200-210, 2010 .

RANZINI, M.; LIMA, W. P. Comportamento hidrológico, balanço de nutrientes e perdas de solo em duas microbacias reflorestadas com Eucalyptus, no Vale do Paraíba, SP. Scientia Forestalis, n. 61, p. 144-159, 2002.

RIBEIRO, K. H. Qualidade da água superficial e a relação com o uso do solo e componentes ambientais na microbacia do rio campestre, Colombo, PR. 2009. 51 f. Dissertação (Mestrado em Ciência do Solo) Universidade Federal do Paraná, Curitiba. 2009.

SABARA, M. G. Comparação ecológica entre rios de menor ordem, drenando bacias cobertas por plantios agrícolas, pastagens e plantios de Eucalyptus grandis, na região do médio Rio Doce (MG). 1999. 259 f. Tese (Doutorado em Ecologia e Recursos Naturais) - Universidade Federal de São Carlos, São Carlos, 1999.

SILVA, F. A. S. ASSISTAT versão 7.6 beta. Campina Grande: Assistência Estatística, Departamento de Engenharia Agrícola do CTRN, Universidade Federal de Campina Grande, 2012. Available from: <http://www.assistat.com>. Access on: 9 sept. 2015.

SILVEIRA, A. L. L. Ciclo hidrológico e bacia hidrográfica. In: TUCCI, C. E. M. Hidrologia: ciência e aplicação. São Paulo: EDUSP, 2001. p. 35-51.

STRECK, E. V.; KÄMPF, N.; DALMOLIN, R. S. D.; KLAMT, E.; NASCIMENTO, P. C.; SCHNEIDER, P.; GIASSON, E.; PINTO, L. F. S. Solos do Rio Grande do Sul. 2nd ed. Porto Alegre: EMATER/RS, 2008. 222 p.

VON SPERLING, M. Principios do tratamento biológico de águas residuárias: introdução à qualidade das águas e ao tratamento de esgotos. 3. ed. Belo Horizonte: UFMG, 2005. 452 p. (v. 1).

\section{Authors contributions}

Jussara Cabral Cruz: Development of main idea, organization of research methodology, contributed to the analysis and discussion of the results and writing of the article, guiding the research.

Mirian Lago Valente: Development of main idea, responsible for developing the work, literature, performing the sampling and laboratory analysis, statistical analysis, analysis of results and writing of the article.

Carine Baggiotto: Contributed in carrying out the collection and laboratory analysis, and writing the article.

Edner Baumhardt: Contributed in the analysis of results and review of the text. 